\title{
FROM UNIVERSITY MATRICULATION REGISTERS TO HISTORICAL PERSONAL DATABASES. DIGITISATION, INDEXING AND PROSOGRAPHIC CLASSIFICATION
}

\author{
INGO RUNDE
}

\begin{abstract}
The tradition of matriculation records at the University of Heidelberg dating back to the founding year 1386 is currently being digitized as part of a DFG project. At the end of the 19th century, these records were made accessible by an edition up to the year 1870. Together with a database structure developed at the University of Duisburg-Essen, the foundations have been laid for the creation of a database of the university members in Heidelberg for the period 1386 to 1920 .
\end{abstract}

Keywords: University of Heidelberg - history of universities - matriculation records - personal databases prosopography

DOI: $10.14712 / 23365730.2020 .25$

Matriculation registers, an important part of cultural heritage and one of the most important sources for research on the history of universities in Germany, were published early but usually without images of the original documents. ${ }^{1}$ These editions, often dating from the 19th century, differ markedly in their periods of coverage, the (register)-layout and the precision of the transcription. Research on the history of the university, which is geared to larger contexts, must therefore work on a very disparate basis in the field of matriculation lists, compile the book editions, check them against the originals in the archives, and often transcribe unedited matriculations for the first time. This diversification is repeated in Internet presentations by university archives, with individual institutions endeavouring to put their matriculation lists online, depending on the resources available. ${ }^{2}$

1 Q.v. last to university matriculation registers Wolfgang MäHRLE, Hochschulmatrikeln, in: Südwestdeutsche Archivalienkunde, URL: $<$ https://www.leo-bw.de/themenmodul/sudwestdeutsche-archivalienkunde/archivaliengattungen/register/hochschulmatrikel> (seen 03.01.2018); Maximilian ScHuH, Matrikeln, in: Jan-Hendryk de Boer - Marian Füssel - Maximilian Schuh (edd.), Universitäre Gelehrtenkultur vom 13.-16. Jahrhundert. Ein interdisziplinäres Quellen- und Methodenhandbuch, Stuttgart 2018, pp. 103-117; Matthias Asche - Susanne HäcKER, Matrikeln, in: Ulrich Rasche (ed.), Quellen zur frühneuzeitlichen Universitätsgeschichte. Typen, Bestände, Forschungsperspektiven, Wiesbaden 2011, pp. 243-267, as well as in preparation Heike HawICKS Ingo Runde (edd.), Universitätsmatrikeln im deutschen Südwesten. Bestände, Erschließung und digitale Präsentation. Beiträge zur Tagung am 16. und 17. Mai 2019 im Universitätsarchiv Heidelberg, Heidelberg 2020 (Heidelberger Schriften zur Universitätsgeschichte 9), and before Eva GIESSLER-WIRsig - Johanna BöHM-KLEIN, Universitäts- und Hochschulmatrikeln, in: Wolfgang Ribbe - Eckhart Henning (edd.), Taschenbuch für Familienforschung, 11. edition, Neustadt a. d. Aisch 1995, pp. 235-269; Thomas Otto AcheLis, Universitätsmatrikeln und ihre Benutzung, Neustadt a. d. Aisch 1963.

2 Q.v. e.g. the online presentations of the matriculation registers of the universities of Duisburg $(<\mathrm{https}: / /$ www.uni-due.de/ub/archiv/universitaetsmatrikel.shtml $>$, seen 30. 07. 2019), Hamburg (<https://www .matrikelportal.uni-hamburg.de/content/index.xml, seen 30. 07. 2019) or Rostock (<http://matrikel 
In order to guarantee a certain uniformity of indexing for Baden-Württemberg, the university archives here have joined forces in an initiative to digitize, according to uniform standards, the oldest records, including the matriculation registers, and make them accessible online. The list-like form of the matriculation entries, as well as their special significance for research on the history of the university and for any enquiries about former members of the university, makes it possible and meaningful to record them together, thus allowing simultaneous searches through several matriculation records from different provenances.

At a conference on the Southwest German university matriculation registers, which took place in May 2019 in the Archives of Heidelberg University, an overview of the type and extent of the existing holdings and of the practices of their digital presentation was given. ${ }^{3}$ At the same time, the conference served as a coordination point for the indexing of matriculation records in the recently started DFG-project "Archival search aids and sources: Digitisation of foundation documents and statutes as well as registers and personnel directories of the Baden-Württemberg university archives in Freiburg, Heidelberg, Hohenheim, Stuttgart and Tübingen". 4

The documents to be recorded in Heidelberg include almost 70 register books dating back to the late medieval period when the university was founded, including the important matriculation registers from 1386 to 1920 and the Rectors' books from 1385 to 1625.5 This project initially aims at the digitisation, cursory indexing and online presentation of the digitised material. In addition, there are plans for a subsequent joint matriculation portal of the university archives in Baden-Württemberg.

In Heidelberg, where the digitization of the register volumes has already been completed ${ }^{6}$ and the preparation of the contents is currently in progress, a pilot project to implement a historical personal database of university members from the beginnings in 1386 to the year 1920 can be started soon thanks to the extensive preliminary indexing work. Thus, a matriculation edition created by G. Toepke at the end of the 19th century for the period $1386-1870^{7}$ has

.uni-rostock.de/>, seen 30.07.2019) and soon the related contributions in the volume H. HAwICKS - I. RUNDE (edd.), Universitätsmatrikeln.

$3<$ https://www.uni-heidelberg.de/uniarchiv/matrikel-tagung.html> (seen 06. 08. 2019); printing of the lectures in the volume H. HAwICKS - I. RUNDE (edd.), Universitätsmatrikeln, is in preparation.

4 Archivische Findmittel und Quellen: Digitalisierung von Gründungsdokumenten und Statuten sowie Matrikeln und Personalverzeichnissen der baden-württembergischen Universitätsarchive Freiburg, Heidelberg, Hohenheim, Stuttgart und Tübingen (<https://gepris.dfg.de/gepris/projekt/415666607>, seen 30. 07. 2019).

$5<$ https://www.uni-heidelberg.de/uniarchiv/forschung/dfg-projekt.html>, seen 30. 07. 2019. The scanning work in Heidelberg alone comprises more than 38,000 pages and is carried out in cooperation with the University Library's Digitization Center. Content indexing is carried out by project staff in the University Archives.

6 Digitized matriculation registers of the University of Heidelberg 1386-1920: <https://digi.ub.uni-heidelberg. de/diglit/uah matrikel>, seen 30. 07. 2019. The volumes up to 1935/36 will follow soon.

7 UAH, M 1-20; Gustav ToEPKe (ed.), Die Matrikel der Universität Heidelberg von 1386 bis 1662. Erster Teil von 1386 bis 1553, Heidelberg 1884; Zweiter Teil von 1554 bis 1662, Heidelberg 1886; Dritter Teil: I. Personenregister, II. Ortsregister, III. Sach- und Wörterregister, Heidelberg 1893; Vierter Teil von 1704 bis 1807, Heidelberg 1903; Fünfter Teil von 1807 bis 1846, Heidelberg 1904; Sechster Teil von 1846 bis 1870, nebst einem Anhang (1. Vorschriften über Immatriculation 1805-1868, 2. Verzeichnis der Rectoren und Prorectoren 1669-1870), Heidelberg 1907; Paul Hintzelmann (ed.), Die Matrikel der Universität Heidelberg. Siebenter Teil enthaltend die Register zu Teil IV bis VI 1704-1870, Heidelberg 1916. The edition can be found as a digital copy at: <https://www.ub.uni-heidelberg.de/helios/digi/unihdmatrikel.html>, seen 30.07.2019. 
already been digitized and an encyclopaedia of the group of professors, the "Heidelberger Gelehrtenlexion" for the years 1386-1986, compiled by D. Drüll, has now been completed. ${ }^{8}$

The only gaps in the Heidelberg register tradition arose in the 17th century during the Thirty Years' War and the War of the Palatinate Succession. Thus the university was closed from 1632 to 1652 and from 1689 to 1703, and the matriculation register for the years 1663-1689 was lost, when it probably became a victim of the flames in the house of the rector of the university during the French sacking of Heidelberg on 22 May $1693 .{ }^{9}$ For the period 1663-1668, however, Toepke was able to refer to a copy in the General State Archive Karlsruhe and published the information in his second volume as 'Appendix I'. 10

G. Toepke's preliminary work is not limited to simply producing an edition of the main volumes of the matriculation register, but is supplemented by much biographical information (Figs. 1/1 and 1/2), which will also be included in the now planned Historical People Database of the University of Heidelberg. Toepke supplemented his second volume with seven appendices, consisting of the copy of the register 1663-1668 in the General State Archives, mentioned above, as well as lists of faculties, doctoral lists and a list of rectors up to $1668 .{ }^{11}$ It should be noted that, for example, in the name lists of the Faculty of Arts, he does not clearly define what is actually in the text and what was added by him as additional information from other sources. This prosopographic information, which goes beyond the mere entries, leads to the technical side of the planned personal database, the aim of which will be a mixture of the best possible digital object indexing and prosopographic documentation.

This digital instrument does not have to be completely recreated, but already exists as a database specialized in personal sources in archives, which is online in a pilot version with the entries from the matriculation book of the Old University of Duisburg. ${ }^{12}$ The detailed manuscript consists of 150 pages and contains 5,938 entries in the register of the Rector. This register was first edited in 1938 by Pastor Wilhelm Rotscheidt (1872-1945) with the title Die Matrikel der Universität Duisburg 1652-1818. ${ }^{13}$ However, this edition has not been digitized as it contains some reading errors, but extensive digital preliminary work has already been carried out. Back in the 1980s Manfred Komorowski began to build up a bio-bibliographic database for the staff of the Old University of Duisburg (1655-1818) in the University Library of Duisburg. In addition to the central data of the curriculum vitae (dates of birth, death, matriculation, doctorate etc.), an attempt was made to research as many

8 Dagmar DrüLl, Heidelberger Gelehrtenlexikon 1386-1651, Berlin - Heidelberg 2002; EAD., Heidelberger Gelehrtenlexikon 1652-1802, Berlin - Heidelberg 1991; EAD., Heidelberger Gelehrtenlexikon 1803-1932, 2. revised and extended edition Berlin - Heidelberg 2019; EAD., Heidelberger Gelehrtenlexikon 1933-1986, Berlin - Heidelberg 2009.

9 Cf. last Ingo Runde, Das Universitätsarchiv Heidelberg. Von der parva archella zum modernen Archivbetrieb, in: Ingo Runde (ed.), Universitätsarchive in Südwestdeutschland. Geschichte - Bestände - Projekte. Tagung anlässlich des 625-jährigen Jubiläums der Ersterwähnung einer Archivkiste der Universität Heidelberg zum 8. Februar 1388, Heidelberg 2013 (Heidelberger Schriften zur Universitätsgeschichte 1), pp. 47-71, here p. 53.

10 G. Toepke (ed.), Die Matrikel, II, pp. 347-360, with note 1. Cf. Manfred Komorowski, Zur Rekonstruktion einer verlorenen Matrikel: Universität Heidelberg 1663-1704, in: H. Hawicks - I. Runde (edd.), Universitätsmatrilen, pp. 83-95.

11 G. Toepke (ed.), Die Matrikel, II, , pp. 347-622.

$12<$ http://matrikeldb.ub.uni-due.de/depa/personenbeleg.jsp> (seen 30. 07. 2019); q.v. Heike HawICKS - Ingo RuNDE, Die Matrikeldatenbank der Alten Universität Duisburg, in: H. Hawicks - I. Runde (edd.), Universitätsmatrikeln, pp. 309-327.

13 Wilhelm Rotscheidt (ed.), Die Matrikel der Universität Duisburg 1652-1818, Duisburg 1938 (online: <http:// digital.ub.uni-duesseldorf.de/id/9077410>, seen 30. 07. 2019). 
academic stations and activities as possible. In addition, there are references to sources and literature. At the end of the 1990s, as part of a DFG-project at the University of Duisburg under the direction of Eckehart Stöve and with the collaboration of Joseph Wijnhoven, Manfred Komorowski and Barbara Fink, a web edition was created in which the old book edition by Wilhelm Rotscheidt (1938) is presented online in a revised version (Fig. 2). ${ }^{14}$

Parallel to the work put in on digitizing the Duisburg matriculations, a database of Medieval Persons and Groups of Persons (Datenbank mittelalterlicher Personen und Personengruppen, abbreviated DMP) existed at the Duisburg chair of medieval history of Dieter Geuenich. Although the source spectrum recorded in it was limited to the period of the early Middle Ages up to about 800 A.D. ${ }^{15}$ There were also lists with large quantities of name documents with a variety of spelling in the focus - a problem that is of great relevance for personal databases, not only for medieval names, but also for name variations from the early modern period. The DMP contains almost 400000 name records, to which about 60000 name records were added, which had been collected in the Internet database of the project at the beginning of the 2000s as part of the DFG-project Name und Gesellschaft. Personennamen als Indikatoren für sprachliche, ethnische, soziale und kulturelle Gruppenzugehörigkeit ihrer Träger (3.-8. Jahrhundert), known by the abbreviation Nomen et gens. ${ }^{16}$ The basis is a digital indexing of name lists from early medieval necrology and fraternization books, originally developed in the 1960 s on punched cards. ${ }^{17}$ As a digital indexing tool, it forms a preliminary work for MGH editions of the Libri memoriales et Necrologia and enables specific name searches through a semi-automatic lemmatisation format for the various early medieval name forms and variants ${ }^{18}$. The record was entered using special characters in a single string in fields divided by slashes (Fig. 3/1) - in the first half of the 1990s, a database mask in DOS format was created to aid data entry with descriptions of the data fields (Fig. 3/2).

14 Eckehart STöve (ed.), Duisburger Universitätsmatrikel (<https://duepublico.uni-duisburg-essen.de/servlets/ DocumentServlet?id=20541>, seen 05. 08. 2019); q.v. Manfred Komorowski, Duisburger Studenten der frühen Neuzeit: Zur neuen Edition der alten Duisburger Universitätsmatrikel, in: Irmgard Hantsche - Dieter Geuenich (edd.), Zur Geschichte der Universität Duisburg 1655-1818, Duisburg 2007 (Duisburger Forschungen 53), pp. 271-292, here pp. 275-283.

15 Q.v. in summary Dieter GeuenICH, Eine Datenbank zur Erforschung mittelalterlicher Personen und Personengruppen, in: Neithard Bulst - Jean-Philippe Genet (edd.), Medieval Lives and the Historian. Studies in Medieval Prosopography, Kalamazoo 1986, pp. 405-417.

16 Q.v. $<$ http://www.neg.uni-tuebingen.de> and last the contributions to the Nomen-et-gens project in the anthology with literature Dieter GEuENICH - Ingo Runde (edd.), Name und Gesellschaft im Frühmittelalter. Personennamen als Indikatoren für sprachliche, ethnische, soziale und kulturelle Gruppenzugehörigkeiten ihrer Träger, Hildesheim - Zürich - New York 2006 (Deutsche Namenforschung auf sprachgeschichtlicher Grundlage 2).

17 Q.v. Karl Schmid, Arbeitsbericht zum Projekt,Personen und Gemeinschaften' im Sonderforschungsbereich 7: „,Mittelalterforschung “, Frühmittelalterliche Studien 7, 1973, pp. 377-391; IDEM, Zum Einsatz der EDV in der mittelalterlichen Personenforschung, Frühmittelalterliche Studien 22, 1988, pp. 53-69; Gerd Althoff, Zum Einsatz der elektronischen Datenverarbeitung in der historischen Personenforschung, Freiburger Universitätsblätter 52, 1977, pp. 17-32; D. GEuENICH, Eine Datenbank; IDEM, A Data Base for Research on Persons and Groups of Persons in the Middle Ages, in: Heinrich Best - Ekkehard Mochmann - Manfred Thaller (edd.), Computers in the Humanities and the Social Sciences. Achievements of the 1980's - prospects for the 1990's, München 1991, pp. 103-108.

18 Q.v. Hermann KAMP, Die automatische Lemmatisierung frühmittelalterlicher Personennamen, Diss. Münster 1976; and last Dieter GEUENICH - Heike HAwICKs, Probleme der Lemmatisierung frühmittelalterlicher Personennamen im interdisziplinären Projekt,Nomen et gens', in: Eva Brylla - Mats Wahlberg (edd.), Proceedings of the 21st International Congress of Onomastic Sciences (ICOS), 19-24 August 2002 Uppsala, Volume 4, Uppsala 2008, pp. 81-90. 
As part of a pilot project for a DFG proposal, an access format (A-DMP) was developed from the original csv version of the DMP at the end of the 1990s, and was presented at the conference of the International Council of Onomastic Sciences (ICOS) in Santiago de Compostela in 1999 (Fig. 4). ${ }^{19}$ Starting from previous versions, this was the first time that index card views with thumbnails and relational database elements had offered the possibility of linking individual entries with images from original pages, allowing direct control of the individual name transcriptions on the screen. The basic csv table format of the data itself was retained.

Based on this, a database concept for the indexing of personal archives (Datenbankkonzept zur Erschließung personenbezogenen Archivguts, abbreviated DEPA) with an executable access database was created in 2003 within the framework of a thesis at the Archives School in Marburg on the basis of various documents from the Civil Status Archives in Brühl and Detmold as well as the Duisburg university register. ${ }^{20}$ Like the DMP before it, the DEPA, which is geared towards Late Medieval and Early Modern archive documents, basically starts from the single document, and as developed for the Access variant of the DMP, it also offers a list view with all the name entries available on one page or in a document (Fig. 5). Modular in design, it can be used to call up further, relationally linked information in the categories of persons, sources, literature and illustrations. In these segments, however, it is also possible to work directly on the person entries independently of the indexing of the individual documents.

The relational structure of DEPA then served as a blueprint for the database of the matriculations of the old University of Duisburg (Fig. 6), which was programmed as a web version in 2007-2010. This was initiated by the newly founded University Archives of Duisburg-Essen supported by Heike Hawicks of the Department of History there as well as in cooperation with the University Library Duisburg-Essen and Stefan Böttcher's Department of Computer Science at the University of Paderborn, whose collaborator Rita Hartel realized the implementation as a web database in the years 2009-2010. ${ }^{21}$

As with its predecessors A-DMP and DEPA, the database of the matriculation register of the Old University of Duisburg is based on each individual entry in the register and attempts to provide the complete context information together with as accurate a dating as possible, which also allows a search in half-year steps. At the same time, it offers the possibility of linking to personal data fed from the bio-bibliographic database and stored in the Comment field.

Since in this case it is only a matter of editing the register of one university, multiple documents for one person do not yet occur frequently, but as soon as matriculations of other universities are included in a search, it will be particularly important to establish controlled

19 Ingo Runde - Tobias Voigt, Neue Möglichkeiten der EDV bei der Erforschung mittelalterlicher Personennamen, in: Ana Isabel Boullón Agrelo (ed.), Actas do XX congreso internacional de ciencias onomásticas, Santiago de Compostela, 20-25 setembro 1999, A Coruña 2002, pp. 1249-1264.

20 Ingo Runde, Datenbankkonzept zur Erschließung personenbezogenen Archivguts vom Mittelalter bis zum Ausgang des 18. Jahrhunderts durch Digitalisierung, Datenaustausch und Lemmatisierungsverfahren, Marburg 2003 (online: <https:/www.archive.nrw.de/lav/archivfachliches/transferarbeiten/Runde_Transferarbeit.pdf>, seen 30. 07. 2019). The database concept was presented to the research community at the International Congress of Onomastic Sciences 2005 in Pisa.

$21<$ http://matrikeldb.ub.uni-due.de/depa/personenbeleg.jsp> (seen 30. 07. 2019); q.v. H. HAWICKS - I. RUNDE, Die Matrikeldatenbank. Technical requirements are a MySQL database and a Tomcat web server, since the interface is based on Java server pages. However, the database can also be converted to Oracle. 
references between the respective individual entries and the persons identified in order to make the peregrinatio academica ${ }^{22}$ visible on the basis of successive entries. This is done in the separate table Personen (Fig. 7), which is based on the individual entries assigned to a person and the bio-bibliographical data from Manfred Komorowski's database mentioned above. In addition, there are directories of matriculation sources and literature, which serve as online aids for all academics conducting research in this area. At the same time, if the source is not available in list form but consists, for example, of detailed personal index cards, it is again possible to edit this separate personal area immediately, independent of the source indexing.

Starting from a handwritten list of names that is typical for matriculation registers, entries made by one's own hand often cause reading problems, as mentioned above. Therefore, the database offers the possibility to check the reading on the original online (Fig. 8). ${ }^{23}$ The list of successively entered persons can, however, not only be viewed in its original form but also, as with the predecessors A-DMP and DEPA, in a tabular view in which the further entries on the page are displayed starting from the respective name document in the register data sheet Personeneintrag (Fig. 9/1).

From each name line, it is possible to switch to the appropriate full entry. The background of this function is the search for recognizable groups that may have changed universities together. In order to make such networks visible, this group search should be set so that the entries do not have to be in the same order and not directly next to each other. It is important that the database has a critical mass of names. This is also a prerequisite for other research approaches, e.g. the denominational distribution of students or supra-regional name research of personal and place names mentioned in the matriculation registers.

But already in the Duisburg entries there are references to the peregrinatio academica, where students are re-enrolled at the original university after a stay at another university e.g. to gain a doctorate. This can be shown with the example of the name search "Andreae". Tobias Andreae (Bremensis, purioris philosophiae studiosus. Accessit ex publica schola Herbornensi), who was first registered in Duisburg in 1652, but spent a year in Leiden before returning to Duisburg. This can already be deduced from the Duisburg entry Tobias Andreae, Saxo Bremensis, 15 Augusti. Veniebat Lugduno-Batavorum ad capessendum gradum in medicina et phil. for the year 1659.

The entries for 1652 and 1659 with identical names can thus be assigned to the same person Tobias Andreae (Fig. 9/2) - a click on the appropriate list entry leads to the name entry with all the context information. In this case, if the matriculations from Leiden were included in the web database, further individual documents would be added to the same person, because there is the entry Tobias Andreae Bremensis for the year 1658, and the next identical entry from the year 1661 shows that the same Tobias Andreae apparently returned

22 Q.v. e.g. the studies of Rainer Christoph SchwingEs, Deutsche Universitätsbesucher im 14. und 15. Jahrhundert. Studien zur Sozialgeschichte des Alten Reiches, Stuttgart 1986 (Veröffentlichungen des Instituts für Europäische Geschichte Mainz 123); Stephanie IrRGang, Peregrinatio academica. Wanderungen und Karrieren von Gelehrten der Universitäten Rostock, Greifswald, Trier und Mainz im 15. Jahrhundert, Stuttgart 2002 (Beiträge zur Geschichte der Universität Greifswald 4).

23 On behalf of the University Archives Duisburg-Essen, the pages of the matriculation register in the Main State Archive Düsseldorf (today North Rhine-Westphalia State Archives, Department Rhineland in Duisburg) were digitized and stored for the web database in a readable and nevertheless easily retrievable size. 
from Duisburg to Leiden a second time afterwards. ${ }^{24}$ The exemplary relationships of the University of Duisburg with the University of Leiden shown here are a good example of the fact that it will be of central importance to enable a comprehensive search in as many matriculation registers as possible of as many universities as possible. ${ }^{25}$ Cartographic visualization options such as those developed for the database of the Repertorium Academicum Germanicum (RAG) might also be used here. ${ }^{26}$

Of central importance for archival practice is the flexibility provided by a modular structure, with which different entry formats are available for very different forms of personal sources. Thus, the prosopographic module can also be processed independent of the indexing of the list entries. In a fourth step, further digital copies can be added to the personal entries. In Heidelberg, these would mainly be the personal files that began in the 16th century and were handed down in dense form from the 19th century onwards, the student files beginning in 1880, and also the rich picture records of university members.

However, when indexed name documents from different locations are linked, the problem of the different spellings of names in the Germanic, Romance and Slavic linguistic areas, which is already latent in university registries, is exacerbated, which is why specific coding formats are provided for the database. ${ }^{27}$

For the forthcoming pilot project of a historical personal database of the University of Heidelberg, the focus will initially be on the period 1386 to 1920 . These 534 years are unproblematic with regard to the protection periods for personal documents and include the considerable number of 115450 matriculation entries in 15 volumes. With the digitisation of these volumes a first step has been taken, now the indexing work follows, in which not only will the Toepke edition, reaching up to the year 1870 be converted into a reviewed and searchable database format, but also nearly 45000 new entries for the period 1871-1920 will be transcribed for the first time.

24 Album studiosorum Academiae Lugduno-Batavae MDLXXV-MDCCCLXXVS, Den Haag 1875, col. 465 und 487 (<https://digital.ub.uni-duesseldorf.de/ihd/content/pageview/8274393>, seen 05. 08. 2019); q.v. to the academic path of Tobias Andreae the contribution of Willem FriJHoff, Die Beziehungen der alten Universität Duisburg zu den Niederlanden, in: I. Hantsche - D. Geuenich (edd.), Zur Geschichte, pp. 39-53, here pp. 41f.

25 Q.v. to this already Ingo Runde, Prototyp einer Web-Datenbank mittelalterlicher und frühneuzeitlicher Universitätsmatrikeln, in: Joan Tort i Donada - Montserrat Montagut i Montagut (edd.), Els noms en la vida quotidiana. Actes del XXIV Congrés Internacional d'ICOS sobre Ciències Onomàstiques, Barcelona 5.-9.09.2011, Barcelona 2014 (Biblioteca Tècnica de Política Lingüística 11), Annex, pp. 1697-1706 (online: <http://www .gencat.cat/llengua/BTPL/ICOS2011/174.pdf>).

$26<$ https://rag-online.org/datenbank/datenbank> (seen 06. 08. 2019); q.v. Kaspar GubleR - Rainer ChristophSchwinges, Repertorium Academicum Germanicum (RAG): A new database for web-based analysis and data visualization, Annali di storia delle università italiane, 21/1, 2017, pp. 13-24; Rainer Christoph SCHwINGES, Doctores so in den püchern lesen. Lebenswege deutscher Gelehrter des 15. bis 16. Jahrhunderts und das Repertorium Academicum Germanicum (RAG), in: Kaspar Gubler - Rainer Christoph Schwinges (edd.), Gelehrte Lebenswelten im 15. und 16. Jahrhundert, Zürich 2018 (Repertorium Academicum Germanicum /RAG/, Forschungen 2), pp. 1-21.

27 Q.v. Stefan Böttcher - Rita Hartel - Heike Hawicks, Namenlemmatisierung in der Web-Datenbank mittelalterlicher und frühneuzeitlicher Universitätsmatrikeln, in: J. T. i Donada - M. Montagut i Montagut (edd.), Els noms en la vida quotidiana, Annex, pp. 283-293 (online: <http://www.gencat.cat/llengua/BTPL /ICOS2011/033.pdf>); Heike Hawicks, Lemmatisierung und Codierung. Zu Möglichkeiten und Problemen der Strukturierung mittelalterlicher und frühneuzeitlicher Namen in Web-Datenbanken, in: H. Hawicks - I. Runde (edd.), Universitätsmatrikeln, pp. 367-384. 


\title{
Conclusion
}

The database model for university matriculations presented here was modelled on the Access database for medieval groups of persons and groups of persons (A-DMP) and implemented using the example of the matriculation register of the Old University of Duisburg. Specified to archive practice, it offers, in a first step, the possibility of making the name material accessible in the respective digitized register volume in a precise and directly verifiable manner. The name material of a volume can then be combined with that of other volumes from the same archive location or other provenances without losing its reference to the original page. In a third step, these collected name entries can be successively merged into personal entries that can be linked with personal entries in the RAG ${ }^{28}$ and, of course, in the Gemeinsamen Normdatei (GND) ${ }^{29}$ - whereby it is to be expected that numerous new GND numbers will be created through the digital indexing of the individual documents in the university registers.

\section{Acknowledgement}

At this point, I would like to thank Peter Bews ( $\dagger$ ) from the English Department of the University of Heidelberg for the competent review of the English translation.

INGO RUNDE

\section{Von Universitätsmatrikeln zur Historischen Personendatenbank. Digitalisierung, Erschließung und prosopographische Zuordnung}

\author{
ZUSAMMENFASSUNG
}

Das hier vorgestellte Datenbankmodell für Universitätsmatrikeln wurde nach dem Vorbild der Access-Datenbank mittelalterlicher Personen- und Personengruppen (A-DMP) erstellt und anhand des Beispiels der Matrikel der Alten Universität Duisburg umgesetzt. Es bietet eine auf die Archivpraxis spezifizierte Möglichkeit, zunächst das Namenmaterial in dem jeweils digitalisierten Matrikelband präzise und direkt überprüfbar zu erschließen. Dieses Namenmaterial eines Bandes kann anschließend mit dem aus weiteren Bänden desselben Archivstandorts oder auch andere Provenienzen vereint werden, ohne den Bezug zur Originalseite zu verlieren. In einem dritten Schritt können diese gesammelten Nameneinträge schließlich sukzessive zu Personeneinträgen zusammengeführt werden, die mit Personeneinträgen im „Repertorium Academicum Germanicum (RAG)“ und natürlich in der „Gemeinsamen Normdatei (GND)“ verlinkt werden können - wobei zu erwarten ist, dass durch die digitale Erschließung der Einzelbelege in den Universitätsmatrikeln auch zahlreiche neue GND-Nummern angelegt werden.

28 Ibid.

$29<$ https://www.dnb.de/DE/Professionell/Standardisierung/GND/gnd_node.html>, seen 06. 08. 2019. 


\title{
OD UNIVERZITNÍCH MATRIK K HISTORICKÝM DATABÁZÍM OSOB. DIGITALIZACE, INDEXOVÁNÍ A PROSOPOGRAFICKÁ KLASIFIKACE
}

\author{
RESUMÉ
}

Model databáze pro univerzitní matriky, který je tu představen, byl vytvořen podle vzoru Access-Databáze středověkých osob a skupin osob (A-DMP) a upraven podle př́íkladu matriky Staré univerzity Duisburg. Nabízí možnost vycházející $\mathrm{z}$ archivní praxe: otevř́t $\mathrm{k}$ hledanému jménu př́slušný svazek matriky $\mathrm{v}$ digitalizované podobě a ověrit údaje. Soubor jmen z jednoho svazku, obsažený v databázi, může být v návaznosti spojen s údaji $\mathrm{z}$ dalších svazkủ stejného archivu nebo jiné provenience, aniž by se ztratila vazba k původní originální straně matriky. Jako třetí krok mohou být tyto údaje napojeny na záznamy o osobách v RAG (Repertorium Academicum Germanicum) a v GND (Gemeinsamen Normdatei). Přitom lze očekávat, že zpřístupnění matričních záznamů přinese řadu nových dat pro GND.

(český překlad Blanka Zilynská)

Dr. Ingo Runde, Archivdirektor

Universitätsarchiv Heidelberg

runde@uniarchiv.uni-heidelberg.de 


\section{Illustrations}

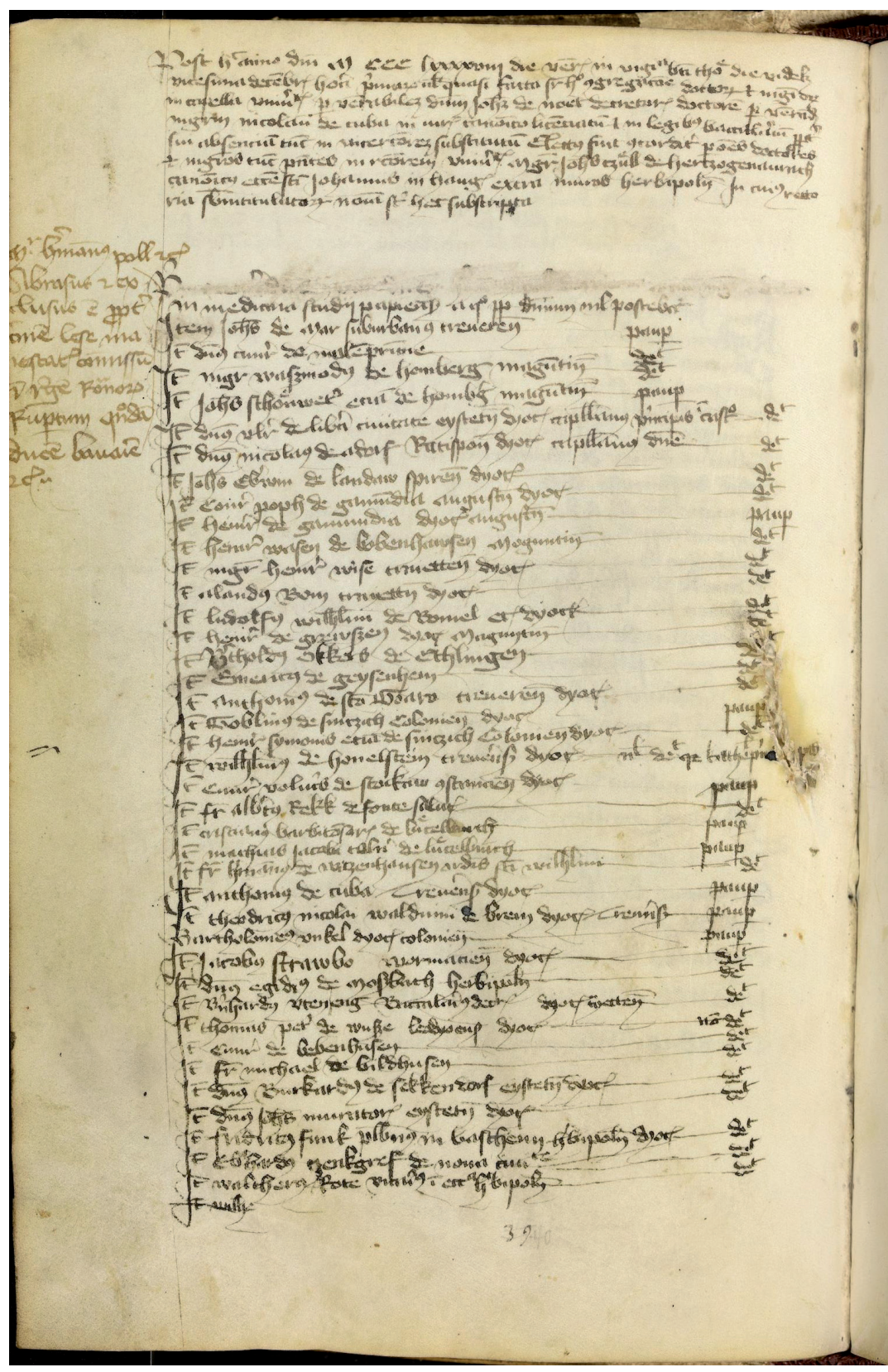

Fig. 1/1: Digital representation of folio $47 \mathrm{v}$ in the first register volume of the University of Heidelberg (UAH, M1, fol. 47v; <https://digi.ub.uni-heidelberg.de/diglit/uah_m1/0098>, 06. 08. 2019). 
(40. Rect.)

I. 47v Post hoc anno domini MCCCLXXXXVIII die Veneris in vigilia beati Thome, die videlicet vicesima Decembris, hora primarum uel quasi facta super hoc congregacione doctorum et magistrorum in capella vniuersitatis per venerabilem dominum Johannem de Noet, decretorum doctorem, per venerabilem magistrum Nicolaum de Cuba, in iure canonico licenciatum et in legibus baccalarium, propter sui absenciam tunc in vicerectorem substitutum ${ }^{1}$, electus fuit concorditer per omnes doctores et magistros tunc presentes in rectorem vniuersitatis magister Johannes Czull de Herczogenaurach, canonicus ecclesie sancti Johannis in Haugis extra muros Herbipolenses, in cuius rectoria subintitulatorum nomina sunt hec subscripta:

Primo

in medicina studij Papiensis, a quo propter dominum nil poscebatur. Item Johannes de Mar suburbanus Treuerensis.

Item dom. Cunradus de Mulenprunne.

Item magister Waszmodus de Homberg Maguntinensis.

Item Johannes Schonweter eciam de Homberg Maguntinensis.

Item dom. Vlricus de $p$. in castro.

Item dom. Nicolaus de Adorf Ratisponensis dyoc. capellanus domine. $\mathrm{d}^{\mathrm{t}}$.

Item Johannes Eberwin de Landaw Spir. dyoc.

Item Conradus Poph de Gamundia dyoc. Augustensis.

Item Heinricus de Gamundia dyoc. Augustensis.

Item Heinricus Wasen de Bobenhawsen Moguntinensis.

Item magister Heinricus Wise ${ }^{3}$ Traiettensis dyoc.

Item Alandus Bom Trayettensis dyoc.

Item Ludolfus Wilhelmi ${ }^{4}$ de Bomel, eciam dyocesis ${ }^{5}$

1 Vergl. A. U. I. 71: «Item feria sexta post natiuitatem beate Marie virginis (13. September 1398) magister Nycolaus de Cuba, rector vniuersitatis, iter arripuit ad curiam Romanam substituendo in vicerectorem venerabilem virum Johannem de Noet» ete. S. A. 5 der vorigen Seite.

${ }_{2}$ Diese Zeile ist fortradirt. Am Rande ist bemerkt: "Magister Hermannus Poll etc. abrasus et exclusus est propter crimen lese maiestatis commissum in regem Rupertum quondam ducem Bauarie». P. war der Leibarzt des Königs, auch magister regens in der medicinischen Facultät. S. die folgende Anmerkung. Er wurde beschuldigt, den Versuch gemacht zu haben, den König zu vergiften. "Teste fama» excludirte ihn die Universität «tamquam membrum putridum et inutile» unterm 3. Mai 1401. Vergl. A. U. I. 11 und 75. Im Calend. acad. I. (s. hinten Anh. I), wie Hautz a. a. O. I. 237 behauptet, befindet sich das betr. Programm nicht.

3 Die 16. Februarij 1399 etc. "recepti fuerunt in membra vniuersitatis actu regentia, singulus tamen eorum in sua facultate, primo venerabilis vir dom. Herm. Poll de Wyenna, magister artium et in medicina doctor studij Papiensis, item magister Heinricus Wyse, in medicina baccalarius, qui et hac ipsa hora de voluntate ac ordinacione domini nostri domini principis deputabatur ad domum magistrorum de collegio (artistarum) presentandus, ut ibidem cum ceteris in artibus laboraret». A. U. I. 72.

${ }^{4}$ b. art. Juli $1400 . \quad 5$ se. Traiectensis.

Fig. 1/2: Digital representation of the edition of folio $47 \mathrm{v}$ in the first register volume of the University of Heidelberg, in: G. TOEPKE (ed.), Die Matrikel, I, p. 68 (<https://digi.ub.uni-heidelberg.de/diglit/matrikel1386/0146>, 06. 08. 2019) 


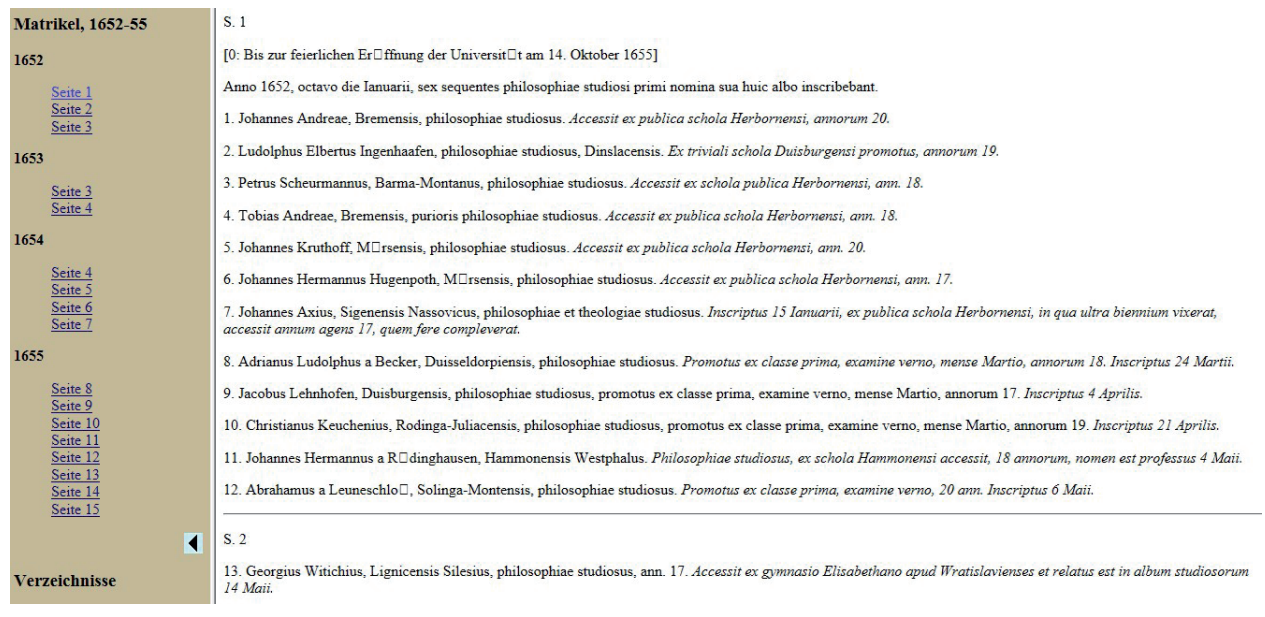

Fig. 2: Online edition of the register of the Old University of Duisburg (<https://duepublico.uni-duisburg-essen.de/servlets/DerivateServlet

/Derivate-22358/1652-55/ante.htm>, seen 05. 08. 2019)

LVBres/3113/V///21r/B3/1/1617////afrid///ah frith/eps.//eps/////BR/1///+

Fig. 3/1: Data record in the DMP for a name document in the Fraternization Book of Brescia in the ASCII basic form - the input fields are listed without descriptions, separated by slashes in a single string.

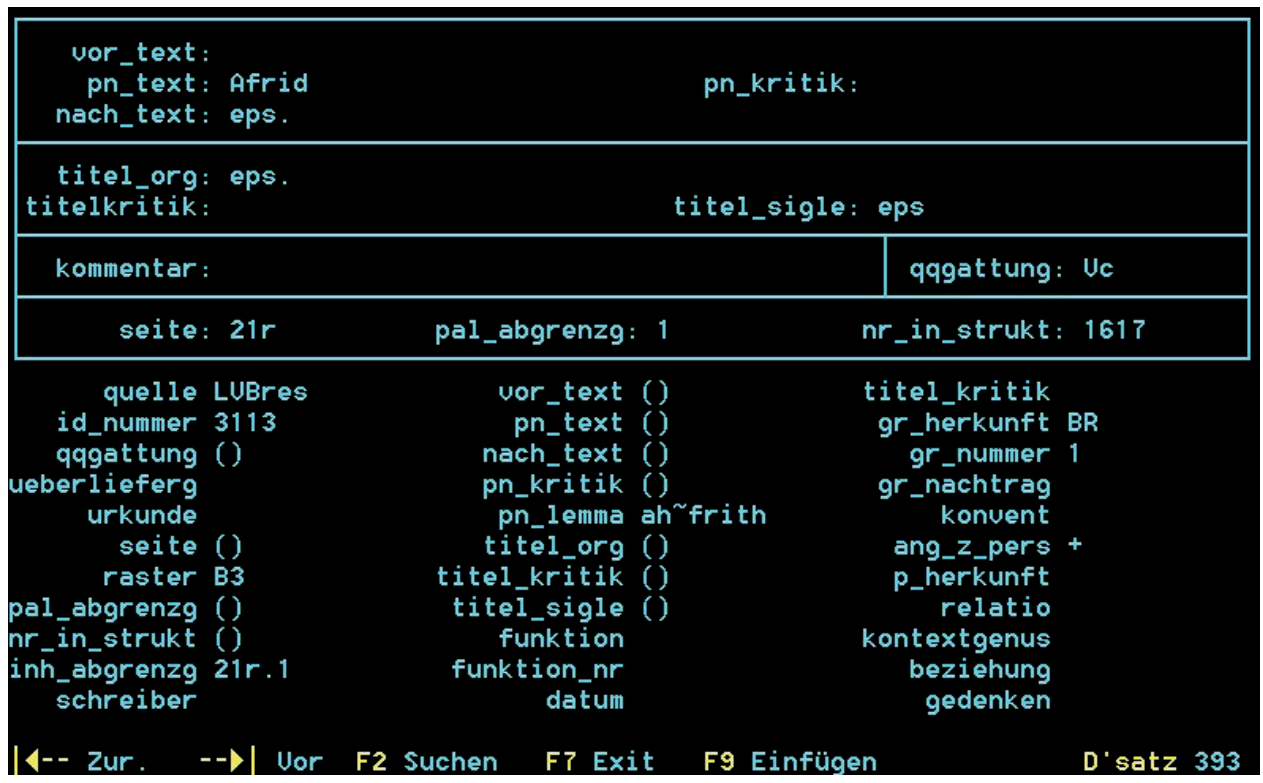

Fig. 3/2: The same data record in the DMP, displayed in the input mask of the DOS-based database of WordPerfect with descriptions of the individual input fields in the first half of the 1990s. 


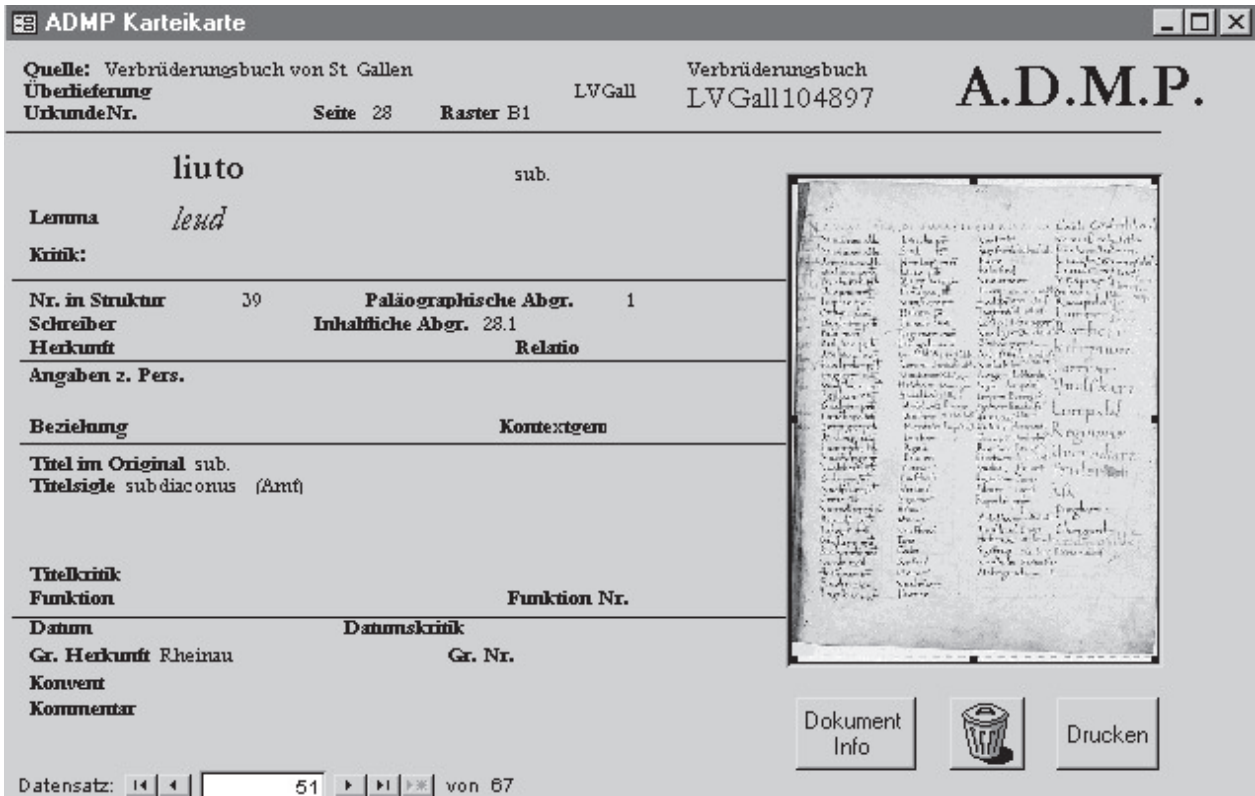

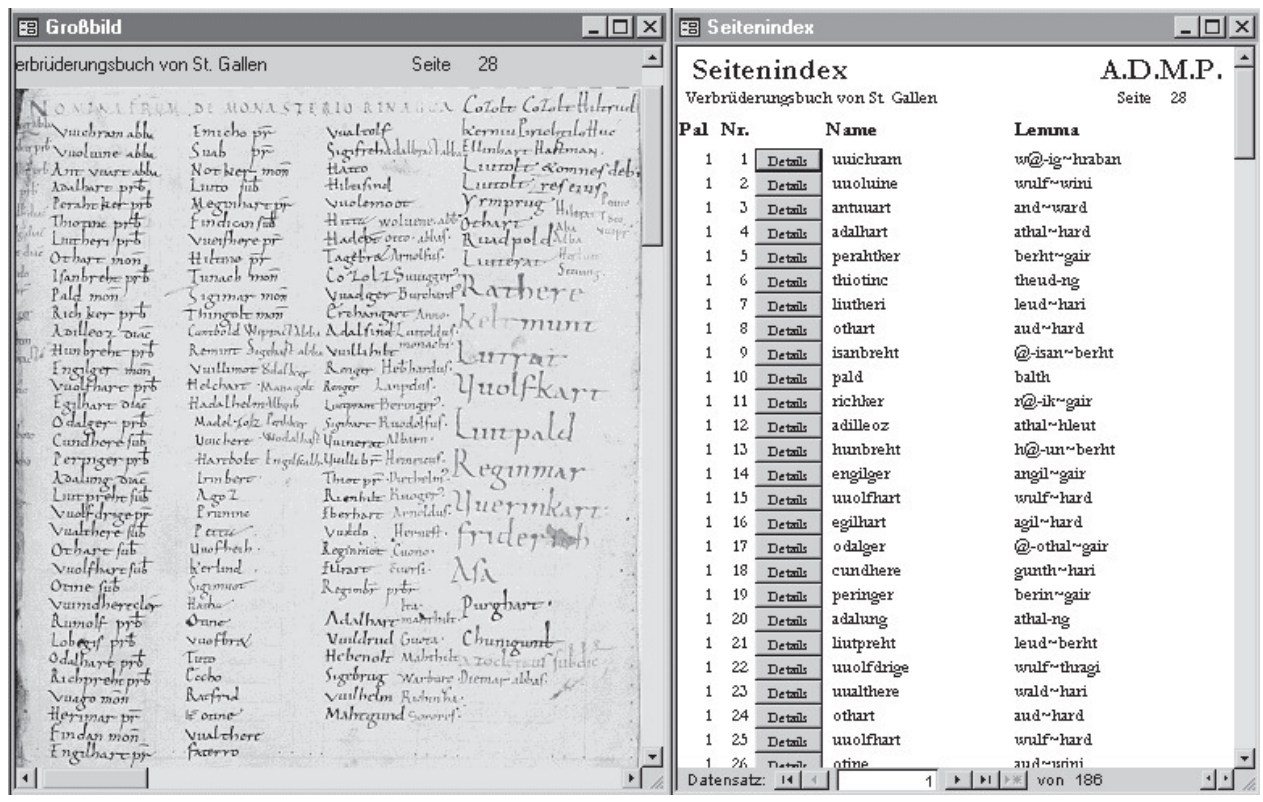

Fig. 4: A-DMP, further development of the DMP at the end of the 1990s with index card view and the possibility to link individual entries with images of original pages and list displays. 


\section{며 Datenbank zur Erschließung personenbezogenen Archivguts (depa)}

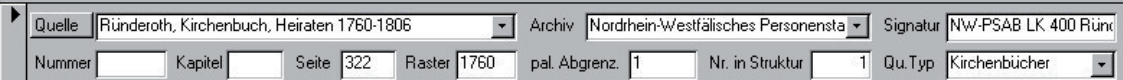

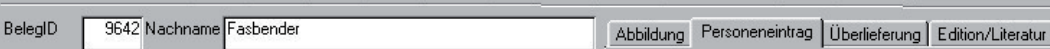

Vorname Wilhelmus Präp. $\square$

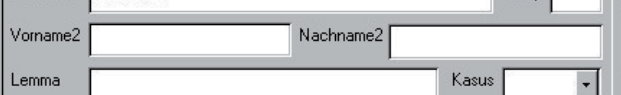

Lemm

Ort-Orig. Bellingroth

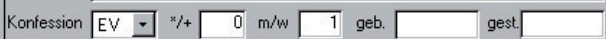

Amt/Stand $\square$ Funktion Bräutigam

Weihe
Kontext

Datumszeile 30 . Jan. 1760

Jahr bis Jahr Monat bis Monat Tag bis Tag Jh. bis.Jh.

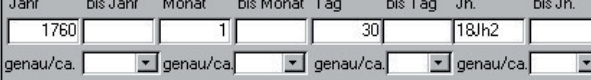

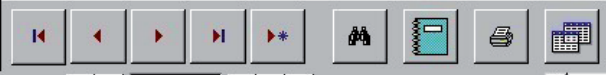

PKZ Verwandtschaft Eheleute

\begin{tabular}{ll} 
Personenkritik & Bild \\
\hline
\end{tabular}

Ehe: Fasbender, Wilhelm - Wegener, Engel [1760 Januar 30]

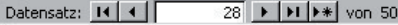

Formularansicht

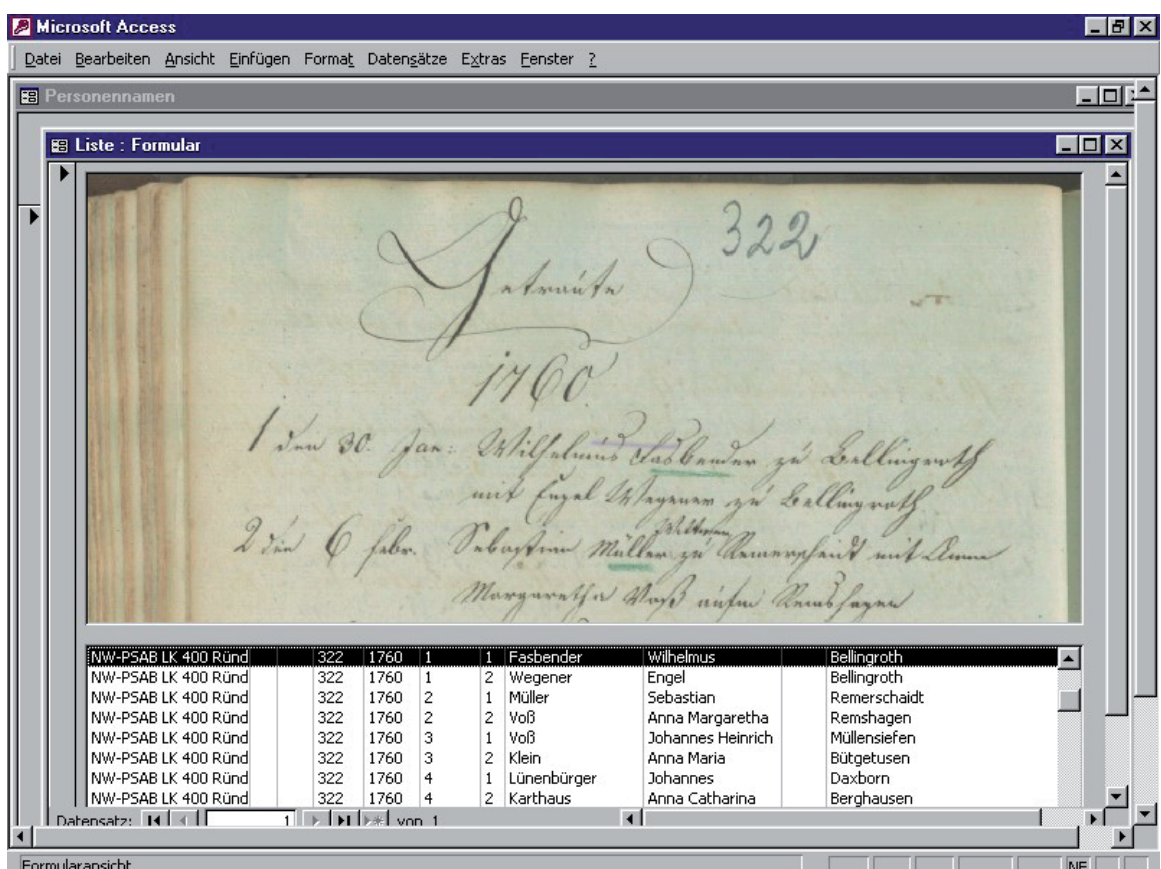

Formularansicht

Personenbezug

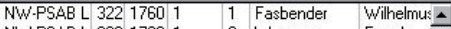

NW.PSAB L 322176012 Wegener Engel 


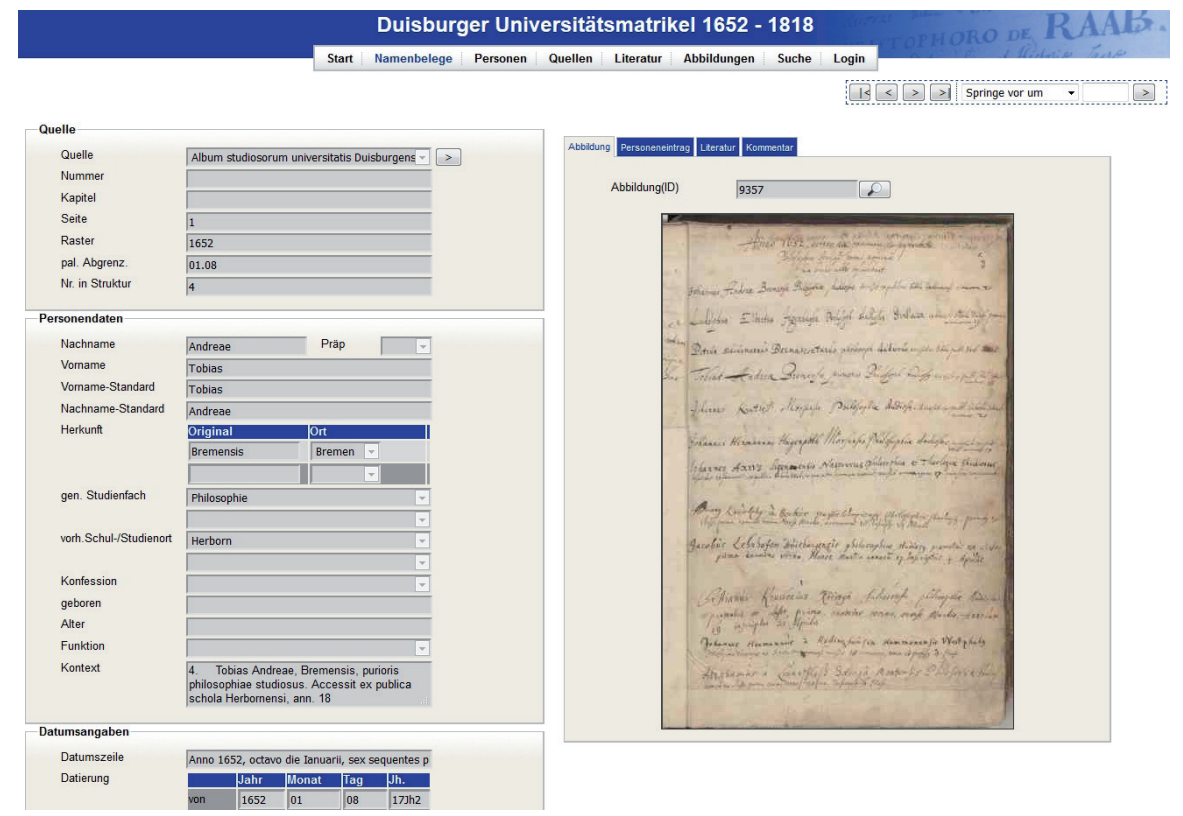

Fig. 6: Web database of the register of the Old University of Duisburg: name document with entry Tobias Andreae from 1 August 1652 (<http://matrikeldb.ub.uni-due.de/depa/personenbeleg.jsp?ID=7>, seen 06. 08. 2019).
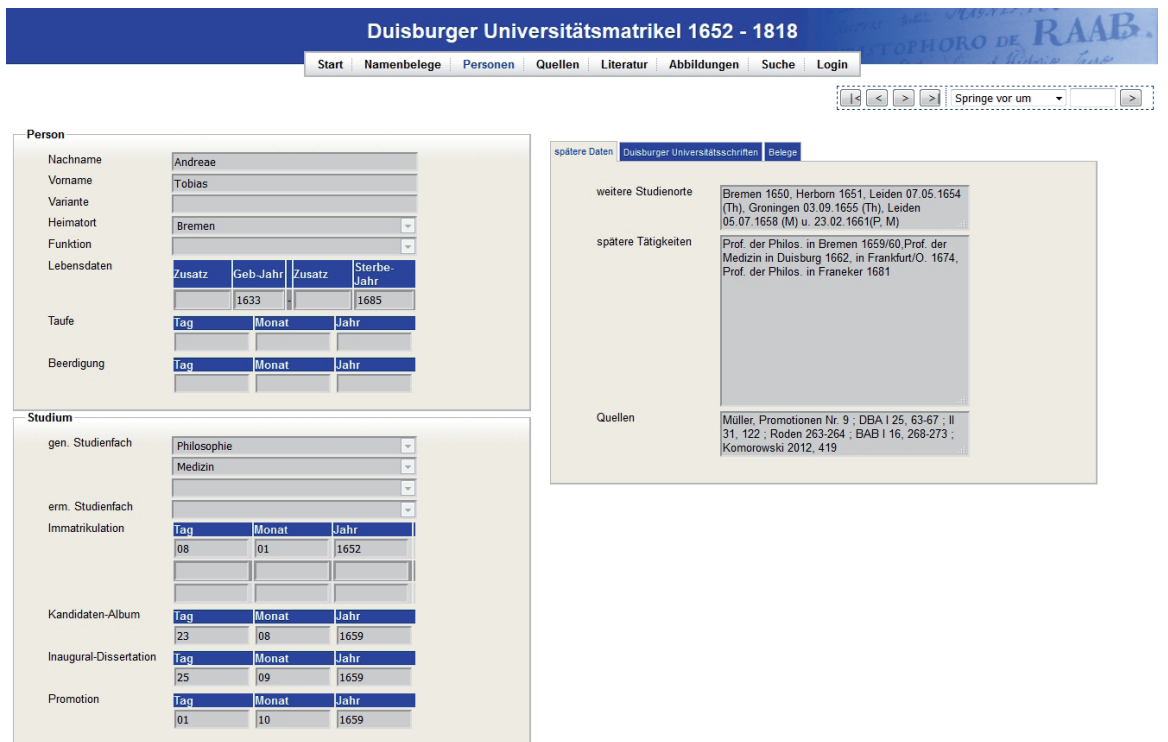

Fig. 7: Web database of the matriculation register of the Old University of Duisburg: personal page about Tobias Andreae

(<http://matrikeldb.ub.uni-due.de/depa/person.jsp?ID=72>, seen 06. 08. 2019). 


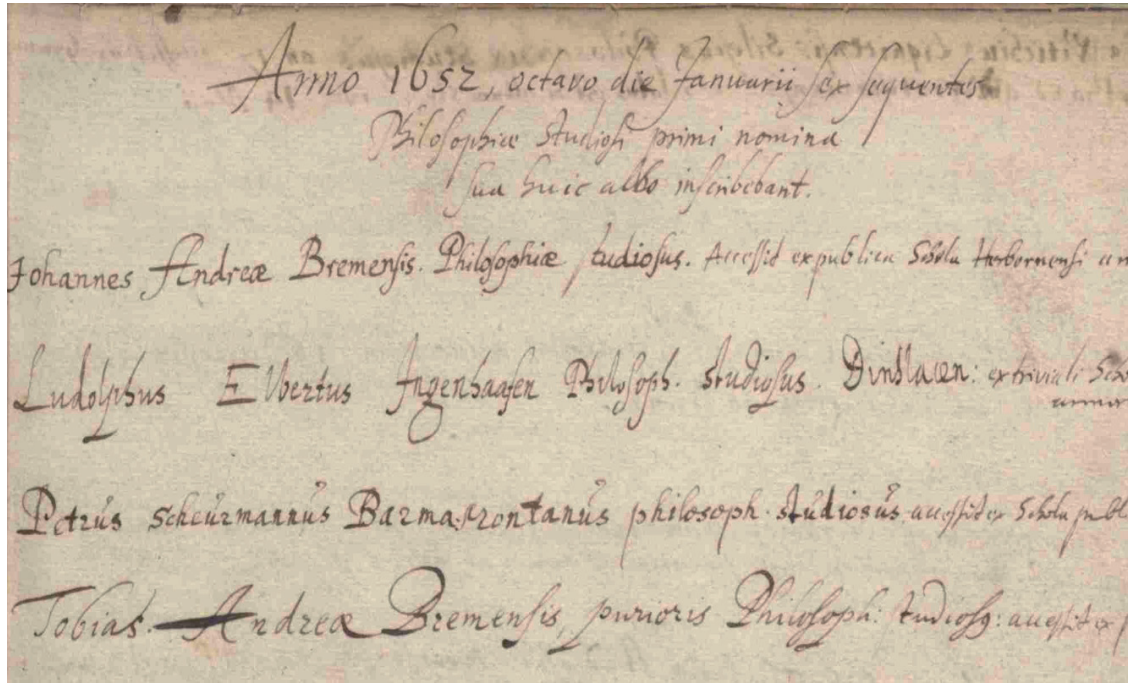

Fig. 8: Web database of the register of the Old University of Duisburg:

View of the digitized original page in highest resolution

(<http://matrikeldb.ub.uni-due.de/depa/img/RW_1264_172_Bl.001.jpg>, seen 06. 08. 2019)

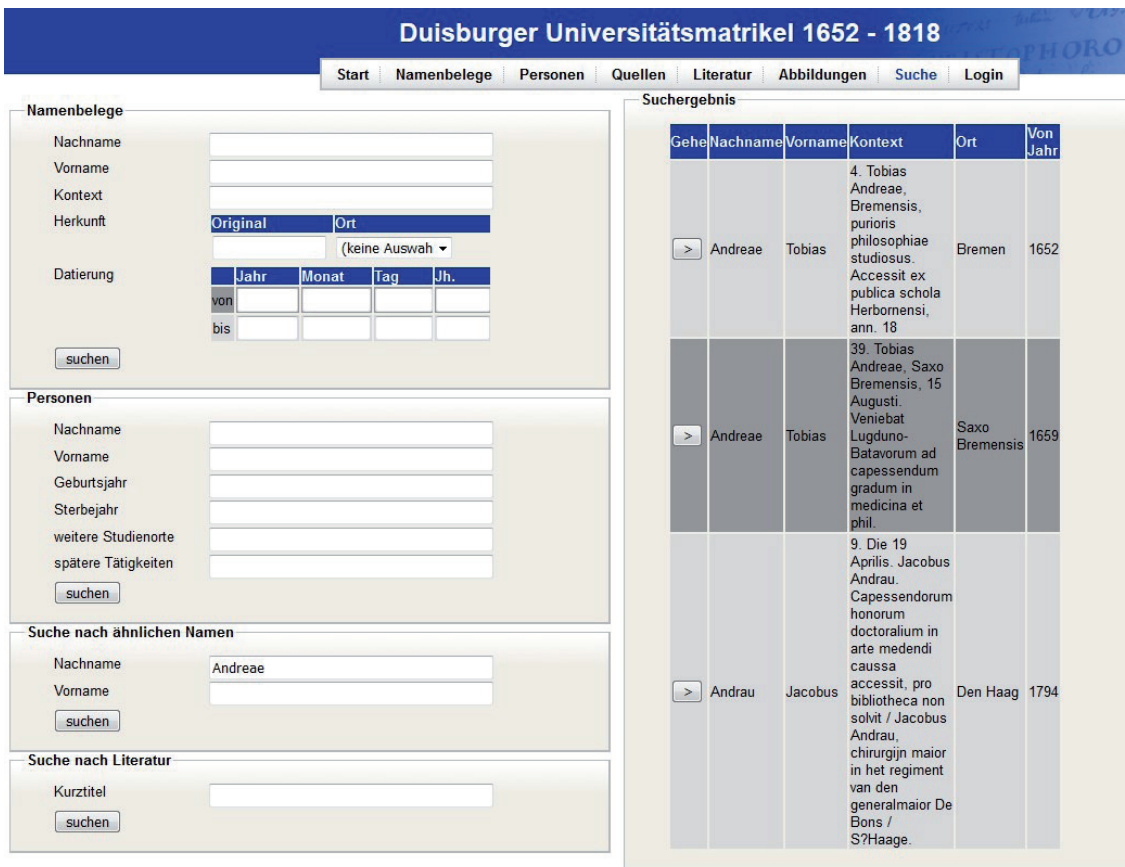

Fig. 9/1: Web database of the Matrikel der Alten Universität Duisburg: personal page about Tobias Andreae with list of personal entries on the same page (<http://matrikeldb.ub.uni-due.de/depa/personenbeleg.jsp?ID=7>, seen 06. 08. 2019). 


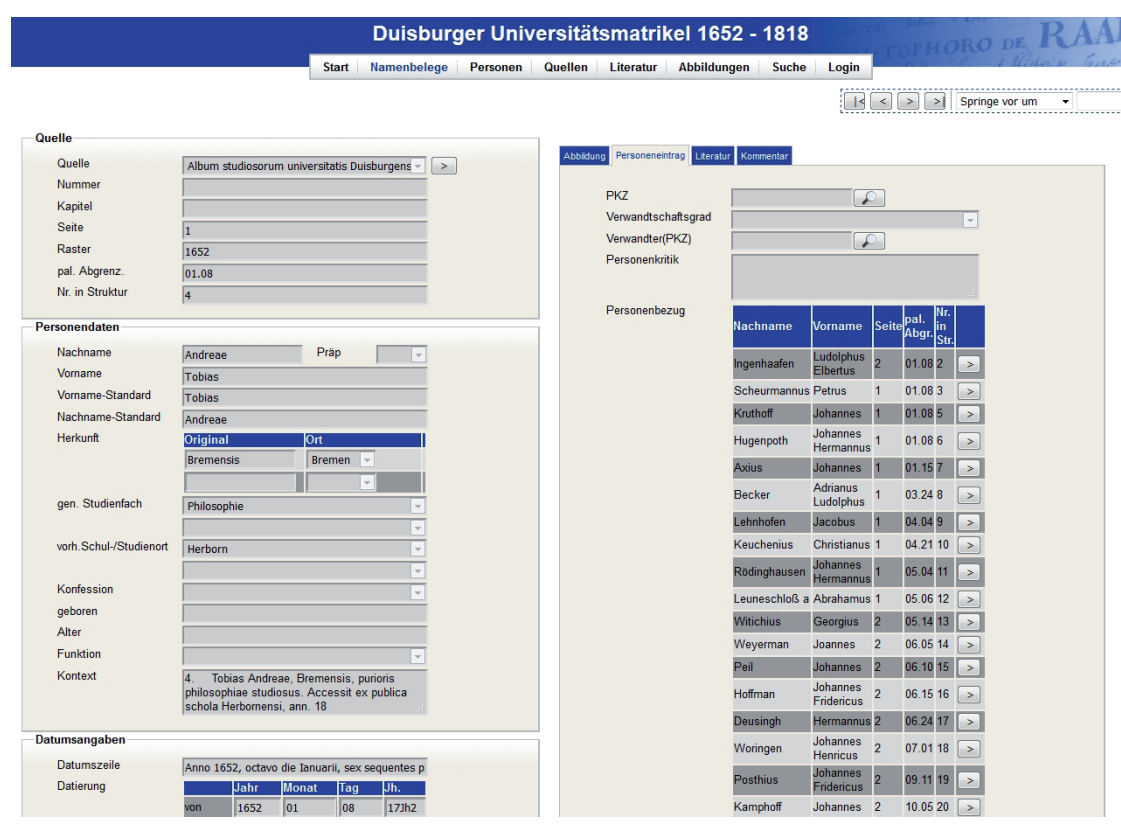

Fig. 9/2: Web database of the register of the Old University of Duisburg:

Search by surname "Andreae"

(<http://matrikeldb.ub.uni-due.de/depa/suche.jsp>, seen 06. 08. 2019) 